\title{
PENGARUH MERGER DAN AKUISISI TERHADAP HARGA SAHAM PERUSAHAAN PENGAKUISISI YANG TERDAFTAR DI BURSA EFEK INDONESIA PERIODE TAHUN 2012-2016
}

\author{
${ }^{1}$ Faisal Saputra, ${ }^{2}$ Ahmad Basid Hasibuan \\ ${ }^{1,2}$ Fakultas Ekonomi, Universitas Darma Persada, Jakarta 13450 \\ e-mail: e-mail: fslsptr@gmail.com
}

\begin{abstract}
Abstrak
Penelitian ini bertujuan untuk menganalisis dan memberikan bukti empiris mengenai pengaruh merger dan akuisisi terhadap harga saham perusahaan pengakuisisi yang terdaftar di Bursa Efek Indonesia periode tahun 2012-2016. Dalam penelitian ini penulis melakukan pengujian dengan menggunakan metode event study yang menghasilkan informasi bahwa ditemukan 6 hari terjadinya return tak normal (abnormal return) yang signifikan, karena nilai return tak normal standarisasi (standardized abnormal return) atau thitung pada 6 hari tersebut lebih atau kurang dari nilai t-tabel. Selain itu, dilakukan juga uji beda menggunakan metode wilcoxon signed rank test yang menghasilkan informasi bahwa tidak terdapat perbedaan rata-rata return tak normal (abnormal return) yang signifikan pada harga saham perusahaan pengakuisisi antara periode sebelum dan sesudah pengumuman merger dan akuisisi, karena nilai signifikansi atau asymp.sig yang diperoleh sebesar 0,421 > 0,05 (a: 5\%; df: $n-1$ ). Simpulan dari hasil tersebut adalah bahwa pengumuman merger dan akuisisi tidak menghasilkan return tak normal (abnormal return) yang signifikan pada harga saham perusahaan pengakuisisi yang melakukan merger dan akuisisi. Hal ini karena return tak normal (abnormal return) sebelum dan sesudah pengumuman merger dan akuisisi tidak berbeda atau sama secara statistik, meskipun disekitar pengumuman merger dan akuisisi tersebut terdapat return tak normal (abnormal return) yang signifikan secara statistik pada 5 hari sebelum dan 1 hari sesudah hari pengumuman merger dan akuisisi.
\end{abstract}

Kata Kunci: Abnormal Return, Event Study, Harga Saham, Pengumuman Merger dan Akuisisi, Wilcoxon Signed Rank Test.

\begin{abstract}
This research aimed to analyze and provide empirical evidence on the effect of mergers and acquisitions on stock prices of acquirer companies listed in the Indonesia Stock Exchange period of 2012-2016. The results of testing using the event study method, the writer found 6 days of significant abnormal return, because the value of standardized abnormal return ( $t$ count) on that 6 days is bigger or smaller than t-table. Meanwhile the results of different tests using the wilcoxon signed rank test method which resulted that there is no significant difference in the average abnormal return on the acquirer's stock price between the period before and after the announcement of mergers and acquisitions, because the value of significance or asymp.sig obtained is $0.421>0.05$ (a: $5 \%$; df: $n-1)$. The conclusion of the research is the announcement of mergers and acquisitions does not show significant abnormal return result on the acquirer's stock price which doing mergers and acquisitions. It is because of the abnormal return before and after the announcement of mergers and acquisitions is statistically equal, eventhough there is a significant abnormal return statistic around the announcement of mergers and acquisitions on 5 days before and 1 day after the day of the announcement of mergers and acquisitions.
\end{abstract}

Keywords: Abnormal Return, Event Study, Merger and Acquisition Annoucement, Stock Price, Wilcoxon Signed Rank Test. 


\section{PENDAHULUAN}

Persaingan usaha yang semakin ketat di era globalisasi saat ini menuntut setiap perusahaan untuk terus berkembang dan meningkatkan daya saing agar dapat mempertahankan eksistensinya serta siap bersaing dengan perusahaan lainnya di seluruh dunia. Untuk mewujudkan hal tersebut, maka diperlukan strategi pengembangan usaha yang tepat. Strategi pengembangan usaha dapat dilakukan oleh perusahaan baik dari sisi internal maupun eksternal. Pengembangan dari sisi internal antara lain dapat dilakukan dengan cara mengembangkan produk yang dipasarkan dan menambah kapasitas produksi perusahaan. Sementara itu, untuk pengembangan dari sisi eksternal dapat dilakukan dengan cara melakukan kombinasi bisnis yang antara lain dapat dilakukan dalam bentuk merger dan akuisisi.

Di Indonesia, kegiatan merger dan akuisisi sudah banyak dilakukan karena dianggap sebagai salah satu strategi yang cukup efektif untuk menghadapi persaingan yang semakin ketat. Berdasarkan data yang diperoleh, kegiatan merger dan akuisisi di Indonesia mengalami peningkatan dari tahun ke tahun, bahkan pada tahun 2017 diperoleh data sebanyak 90 kegiatan merger dan akuisisi yang terjadi.

Menurut Foster (1986; 377) dalam Jogiyanto (2017; 609), pengumuman merger, ambilalih, dan divestasi, merupakan salah satu faktor yang dapat mempengaruhi harga saham perusahaan. Oleh karena itu, bagi seorang investor maupun calon investor pengumuman merger dan akuisisi seharusnya menjadi salah satu hal yang menjadi perimbangan dalam melakukan investasi, dengan memanfaatkan ataupun mengantisipasi hal-hal yang mungkin akan terjadi dari pengumuman merger dan akuisisi tersebut.

Hasil penelitian sebelumnya terkait dengan pengaruh pengumuman merger dan akuisisi terhadap harga saham dengan indikator abnormal return yang diteliti dengan menggunakan metode event study, diperoleh hasil yang beragam antara lain sebagai berikut:

a. penelitian yang dilakukan oleh Elad (2017), memberikan hasil bahwa peristiwa akuisisi secara signifikan terkait dengan abnormal return yang pada uji statistik menunjukkan bahwa pasar merespon positif berita akuisisi tersebut;

b. penelitian yang dilakukan oleh Rahmad, Arshad, \& Khalil (2017), memberikan hasil bahwa pasar merespon negatif terhadap aktivitas merger dan akuisisi yang dilakukan perusahaan pada sektor perbankan di Pakistan;

Beragamnya hasil penelitian sebagaimana dijelaskan di atas, membuat kerancuan terkait pengaruh pengumuman merger dan akuisisi terhadap harga saham perusahaan yang melakukan merger dan akuisisi tersebut.

Berdasarkan hal-hal sebagaimana dijelaskan di atas, penulis melakukan penelitian lanjutan untuk memberikan simpulan yang diharapkan dapat lebih memberikan kejelasan 
terkait pengaruh merger dan akuisisi terhadap harga saham perusahaan yang melakukan kegiatan merger dan akuisisi tersebut.

\section{KAJIAN PUSTAKA}

\section{Konsep Merger dan Akuisisi}

Berdasarkan Pernyataan Standar Akuntansi Keuangan (PSAK) nomor 22 (penyesuaian 2014) tentang kombinasi bisnis, dinyatakan bahwa kombinasi bisnis adalah suatu transaksi atau peristiwa lain dimana pihak pengakuisisi memperoleh pengendalian atas satu atau lebih bisnis. Secara umum kombinasi bisnis atau penggabungan usaha dapat berupa merger, akuisisi, dan konsolidasi. Menurut Christensen et. al. (2014; 10), penggabungan usaha memiliki 3 bentuk utama, yaitu:

a. Merger statutori (statutory merger) merupakan jenis penggabungan usaha dimana hanya satu dari perusahaan yang bergabung yang akan bertahan sedangkan perusahaan lainnya dibubarkan.

b. Konsolidasi statutori (statutory consolidation) adalah kombinasi bisnis dimana kedua atau lebih perusahaan yang bergabung dibubarkan dan aset serta liabilitas dari kedua atau lebih perusahaan tersebut ditransfer ke perusahaan yang baru dibentuk.

c. Akuisisi saham (stock acquisition) terjadi ketika satu perusahaan mengakuisisi atau membeli saham berhak suara dari perusahaan lain dan kedua perusahaan tersebut terus beroperasi sebagai entitas hukum yang terpisah, tetapi saling terkait atau terafiliasi.

Menurut Gitman (2009; 764) ada beberapa alasan perusahaan melakukan penggabungan, baik melalui merger maupun akuisisi, yaitu sebagai berikut.

a. Pertumbuhan atau diversifikasi (Growth or Diversification).

b. Sinergi (Synergy).

c. Meningkatkan dana (Fund Raising).

d. Menambah keterampilan manajemen atau teknologi (Increased Managerial Skill or Technology).

e. Pertimbangan pajak (Tax Consideration).

f. Meningkatkan likuiditas pemilik (Increased Ownership Liquidity).

g. Melindungi diri dari pengambilalihan (Defense Against Takeover).

Dari penjelasan di atas, diketahui bahwa merger dan akuisisi merupakan suatu kegiatan yang diharapkan dapat mengembangkan perusahaan menjadi lebih besar dan berdaya saing tinggi, sehingga seharusnya kegiatan merger dan akuisisi yang dilakukan akan mendapat respon positif dari pasar atau para investor. 


\section{Konsep Saham}

Saham adalah sebagai tanda penyertaan atau kepemilikan seseorang atau badan dalam suatu perusahaan atau perseroan terbatas (Darmadji dan Fakhrudin, 2012; 5). Secara umum saham terbagi atas dua jenis, yakni saham biasa (common stocks) dan saham preferen (preferred stocks). Saham biasa merupakan kelompok saham yang mencerminkan hak kepemilikan serta memiliki risiko tinggi dan pengembalian tinggi atas kinerja perusahaan, sementara saham preferen adalah kelompok khusus saham yang memiliki fitur yang tidak dimiliki oleh saham biasa (Subramanyam, 2016; 228). Perbedaan utama antara kedua jenis saham tersebut adalah adanya hak suara dalam Rapat Umum Pemegang Saham (RUPS) bagi pemegang saham biasa, sementara bagi pemegang saham preferen tidak memiliki hak suara dalam RUPS. Selain itu untuk pemegang saham preferen mendapat hak prioritas atas likuidasi perusahaan dibandingkan dengan saham biasa.

\section{Hipotesis Pasar Efisien}

Menurut Beaver (1989) dalam Jogiyanto (2017; 616), secara umum efisiensi pasar (market efficiency) adalah hubungan antara harga-harga sekuritas dengan informasi. Jika pasar bereaksi dengan cepat dan akurat untuk mencapai harga keseimbangan baru yang sepenuhnya mencerminkan informasi yang tersedia, maka kondisi pasar seperti ini disebut dengan pasar efisien. Pasar efisien yang ditinjau dari sudut informasi saja disebut dengan efisiensi pasar secara informasi (informationally efficient market). Sedangkan pasar efisien yang ditinjau dari sudut kecanggihan pelaku pasar dalam mengambil keputusan berdasarkan informasi yang tersedia disebut dengan efisiensi pasar secara keputusan (decisionally efficient market) (Jogiyanto, 2017; 605).

Menurut Fama (1970) dalam Jogiyanto $(2017 ; 606)$, terdapat tiga macam bentuk utama dari efisiensi pasar berdasarkan ketiga macam bentuk dari informasi, yaitu:
a. efisiensi pasar bentuk lemah (weak form);
b. efisiensi pasar bentuk setengah kuat (semistrong form); dan
C. efisien pasar bentuk kuat (strong form).

Selanjutnya Fama (1991) dalam Jogiyanto (2017; 631) mengusulkan untuk mengubah nama ketiga macam kategori pengujian bentuk efisiensi pasar tersebut. Nama-nama pengujian yang diusulkan adalah sebagai berikut.
a. Pengujian-pengujian efisiensi pasar bentuk lemah diganti menjadi pengujian-pengujian terhadap pendugaan return (tests for return predictability).
b. Pengujian-pengujian efisiensi pasar bentuk setengah kuat dirubah menjadi studi-studi peristiwa (event studies).
c. Pengujian-pengujian efisiensi pasar bentuk kuat diusulkan menjadi pengujian-pengujian terhadap informasi privat (tests for private information).




\section{Event Study}

Menurut Tandelilin $(2017 ; 243)$ Penelitian yang mengamati dampak dari pengumuman informasi terhadap harga sekuritas sering disebut dengan event studies. Penelitian event studies umumnya berkaitan dengan seberapa depan suatu informasi yang masuk ke pasar dapat tercermin pada harga saham. Studi peristiwa (event study) merupakan studi yang mempelajari reaksi pasar terhadap suatu peristiwa (event) yang informasinya dipublikasikan sebagai suatu pengumuman.

\section{METODE PENELITIAN}

Populasi dalam penelitian ini adalah seluruh perusahaan publik (yang sahamnya diperdagangkan di Bursa Efek Indonesia) yang melakukan merger dan akuisisi sebagai pihak pengakuisisi pada periode tahun 2012-2016. Sampel ditetapkan berdasarkan metode purposive sampling, dengan menetapkan beberapa kriteria sebagai berikut.

a. Sampel adalah perusahaan pengakuisisi yang masih terdaftar di Bursa Efek Indonesia yang melakukan kegiatan merger dan akuisisi antara tahun 2012-2016.

b. Tersedia data terkait harga saham perusahaan yang terdaftar di Bursa Efek Indonesia minimal 60 hari sebelum peristiwa sampai dengan 60 hari setelah peristiwa merger dan akuisisi.

c. Tersedia data yang memadai terkait informasi kegiatan merger dan akuisisi yang dilakukan berupa tanggal efektif merger dan akuisisi yang dilakukan.

d. Dalam hal antara tahun 2012-2016 perusahaan melakukan beberapa kegiatan merger dan akuisisi, maka hanya diambil satu kegiatan merger dan akuisisi dari perusahaan tersebut pada kegiatan merger dan akuisisi terakhir yang dilakukan.

Dalam penelitian ini data yang digunakan adalah data sekunder. Menurut Indriantoro dan Supomo $(2016 ; 147)$, data sekunder merupakan data penelitian yang diperoleh peneliti secara tidak langsung melalui media perantara (diperoleh dan dicatat oleh pihak lain). Data sekunder dimaksud adalah data perusahaan publik pengakuisisi yang melakukan merger dan akuisisi yang diperoleh dari database yang terdapat pada The Indonesia Capital Market Institute (TICMI) dan Komisi Pengawas Persaingan Usaha Republik Indonesia (KPPU-RI). Dari data yang dikumpulkan, diperoleh populasi sebanyak 71 perusahaan pengakuisisi, dengan sampel sebanyak 47 perusahaan.

Penelitian ini dilakukan dengan menggunakan teknik analisis dalam penelitian ini dilakukan dengan event study dan uji beda rata-rata untuk dua sampel berpasangan (paired sample $t$-test) atau wilcoxon signed rank test, untuk mengolah dan membahas data yang diperoleh. Metode event study digunakan untuk menganalisis apakah pengumuman merger dan akuisisi berpengaruh terhadap harga saham perusahaan dengan indikator abnormal 
return. Uji beda rata-rata dua sampel berpasangan (paired sample $t$-test) atau wilcoxon signed rank test (tergantung normalitas data), digunakan untuk menganalisis apakah terdapat perbedaan rata-rata abnormal return antara sebelum dan sesudah peristiwa yang signifikan, sebagai akibat dari pengumuman merger dan akuisisi.

\section{Event Study}

Langkah-langkah event study yang dilakukan dalam penelitian ini adalah sebagai berikut.

a. Menetapkan rentang waktu event study penelitian. Rentang waktu dalam event study terdiri dari estimation window, event window, dan post-event window.

1) Estimation window tidak diobservasi dalam penelitian ini karena dasar perhitungan return ekspektasian menggunakan pendekatan market-adjusted model yang menganggap bahwa penduga yang terbaik untuk mengestimasi return suatu sekuritas adalah return indeks pasar pada saat tersebut.

2) Event window diobservasi selama 121 hari, mulai dari 60 hari sebelum tanggal pengumuman merger dan akuisisi (hari -60) sampai 60 hari setelah tanggal pengumuman merger dan akuisisi (hari +60 ) atau 60 hari sekitar tanggal peristiwa, yaitu 60 hari sebelum pengumuman, hari pengumuman, dan 60 hari setelah pengumuman. Abnormal return akan dihitung pada hari -60 s.d. -1 (untuk mengetahui ada tidaknya kebocoran informasi, hari 0 (reaksi pasar pada tanggal pengumuman), dan hari +1 s.d. +60 (untuk mengetahui kecepatan reaksi pasar).

3) Post-event window tidak diobservasi karena tidak dilakukan pendalaman studi empiris mengenai pengumuman untuk jangka waktu pendek atau pengumuman yang berjangka waktu panjang.

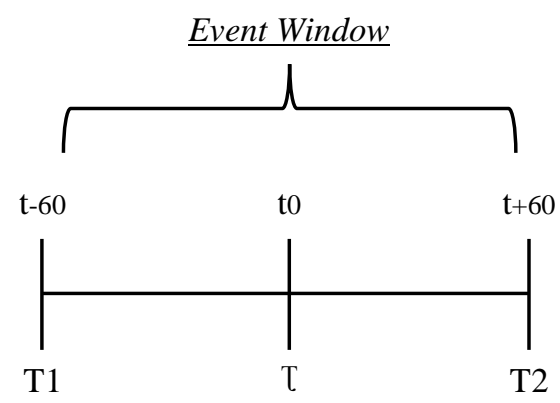

\section{Gambar 3.1. Event Window}

dimana:

$T$

: event date

T1 sampai T2

event window 121 hari

b. Menetapkan kriteria terpilih untuk perusahaan yang termasuk dalam study, dengan sampel terpilih sebagaimana dijelaskan di atas.

c. Penilaian dampak sebuah peristiwa dengan proksi return tak normal (abnormal return), dilakukan dengan menggunakan rumus sebagai berikut (Jogiyanto, 2017; 668). 


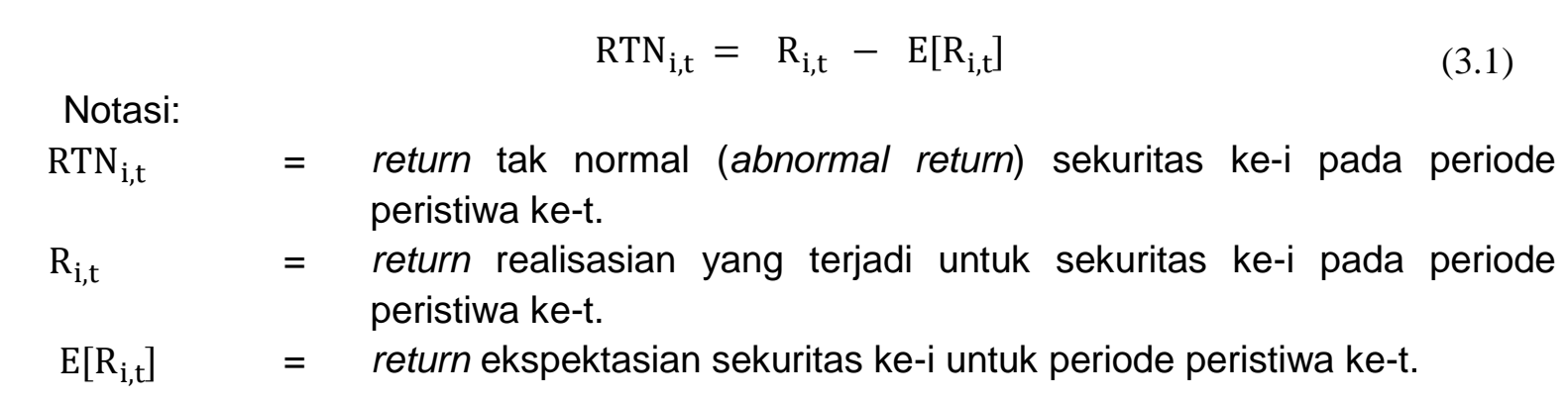

1) Return realisasian atau return sesungguhnya dapat dihitung dengan rumus sebagai berikut (Jogiyanto, 2017; 668).

$$
R_{i, t}=P_{i, t}-P_{i, t-1}
$$

Notasi:

$\mathrm{R}_{\mathrm{i}, \mathrm{t}} \quad=\quad$ return realisasian sekuritas ke-i pada periode peristiwa ke-t.

$\mathrm{P}_{\mathrm{i}, \mathrm{t}} \quad=\quad$ adjusted closing price sekuritas ke-i pada pada hari ke-t.

$\mathrm{P}_{\mathrm{i}, \mathrm{t}-1}=$ adjusted closing price sekuritas ke-1 pada hari sebelum hari ke-t.

2) Return ekspektasian dalam penelitian ini menggunakan model sesuaian-pasar (market-adjusted mode). Dalam model market-adjusted model return sekuritas yang diestimasi adalah sama dengan return indeks pasar, dengan persamaan sebagai berikut (Jogiyanto, 2017; 679).

Notasi:

$$
\mathrm{E}\left[\mathrm{R}_{\mathrm{i}, \mathrm{t}}\right]=\mathrm{R}_{\mathrm{m}, \mathrm{t}}
$$

$\mathrm{E}\left[\mathrm{R}_{\mathrm{i}, \mathrm{t}}\right] \quad=\quad$ return ekspektasian sekuritas ke-i untuk periode peristiwa ke-t.

$\mathrm{R}_{\mathrm{m}, \mathrm{t}} \quad=\quad$ return indeks pasar pada periode peristiwa ke-t yang dapat dihitung dengan rumum $\mathrm{R}_{\mathrm{m}, \mathrm{t}}=$ (IHSGt - IHSGt-1) / IHSGt-1, dengan IHSG adalah indeks harga saham gabungan.

3) Menguji rata-rata return tak normal. Pengujian adanya abnormal return dilakukan secara agregat dengan menguji rata-rata return tak normal seluruh sekuritas secara cross-section untuk tiap-tiap hari di periode peristiwa. Perhitungan ini dapat dilakukan dengan menggunakan rata-rata aritmatika sebagai berikut (Jogiyanto, 2017; 680).

$$
\operatorname{RRTN}_{\mathrm{t}}=\frac{\sum_{i=1}^{k} \mathrm{RTN}_{\mathrm{i}, \mathrm{t}}}{\mathrm{k}}
$$

Notasi:

$\begin{array}{lll}\mathrm{RRTN}_{\mathrm{t}} & =\quad \begin{array}{l}\text { rata-rata return tak normal (average abnormal return) pada } \\ \text { hari ke-t. }\end{array} \\ \mathrm{RTN}_{\mathrm{i}, \mathrm{t}} & =\begin{array}{l}\text { return tak normal (abnormal return) untuk sekuritas ke-i pada } \\ \text { hari ke-t. }\end{array} \\ \mathrm{K} & =\begin{array}{l}\text { jumlah sekuritas yang melakukan merger dan akuisisi yang } \\ \text { diteliti. }\end{array}\end{array}$


4) Menganalisis return tak normal (abnormal return) melalui uji statistik untuk melihat signifikansi return tak normal (abnormal return) yang ada di periode peristiwa. Signifikansi yang dimaksud adalah bahwa return tak normal (abnormal return) tersebut secara statistik signifikan tidak sama dengan nol, yang dilakukan dengan pengujian-t (t-test) (Jogiyanto, 2016; 686). Pengujian-t dilakukan dengan dengan langkah-langkah sebagai berikut.

a) Menghitung kesalahan standar estimasi yang didasarkan pada deviasi standar return-return tak normal dari sejumlah sekuritas secara cross-section untuk setiap hari di periode peristiwa, dengan rumus sebagai berikut (Jogiyanto, 2017; 701).

$$
\mathrm{KSE}_{\mathrm{t}}=\sqrt{\frac{\sum_{\mathrm{i}=1}^{\mathrm{k}}\left(\mathrm{RTN}_{\mathrm{i}, \mathrm{t}}-\overline{\mathrm{RTN}}_{\mathrm{t}}\right)^{2}}{(\mathrm{k}-1)}} \cdot \frac{1}{\sqrt{\mathrm{k}}}
$$

Notasi:

$\mathrm{KSE}_{\mathrm{t}} \quad=\quad$ kesalahan standar estimasi untuk hari ke-t di periode peristiwa.

$\mathrm{RTN}_{\mathrm{i}, \mathrm{t}}=$ return tak normal sekuritas ke-i untuk hari ke-t di periode peristiwa.

$\overline{\mathrm{RTN}}_{\mathrm{t}} \quad=$ rata-rata return tak normal k-sekuritas untuk hari ke-t di periode peristiwa.

$\mathrm{K}=$ jumlah sekuritas.

b) Menghitung nilai return tak normal (abnormal return) standarisasi atau nilai thitung, dengan menggunakan rumus sebagai berikut (Jogiyanto, 2017; 702)

$$
\mathrm{RTNS}_{\mathrm{t}}=\frac{\overline{\mathrm{RTN}}_{\mathrm{t}}}{\mathrm{KSE}_{\mathrm{t}}}
$$

Notasi:

RTNS $_{\mathrm{t}}=$ return tak normal standarisasi portofolio untuk hari ke-t di periode peristiwa.

$\overline{\mathrm{RTN}}_{\mathrm{t}} \quad=\quad$ rata-rata return tak normal k-sekuritas untuk hari ke-t di periode peristiwa.

$\mathrm{KSE}_{\mathrm{t}} \quad=\quad$ kesalahan standar estimasi untuk hari ke-t di periode peristiwa.

c) Merumuskan formula untuk pengujian hipotesis.

d) Menentukan tingkat signifikansi. Penelitian ini menggunakan taraf nyata sebesar $5 \%$, dengan derajat kebebasan (degree of freedom) $n-1$.

e) Mengambil keputusan dengan membandingkan nilai t-hitung dengan t-tabel, dengan kriteria sebagai berikut:

i. apabila thitung terletak diantara $+\mathrm{t} a / 2 ;(n-1)$ dan $-\mathrm{t} a / 2 ;(n-1)$ maka Ho diterima; dan

ii. apabila thitung lebih kecil dari $-\mathrm{t} a / 2 ;(n-1)$ atau thitung lebih besar dari $+\mathrm{t} a / 2$; (n-1) maka Ho ditolak.

f) Menarik simpulan. 


\section{Uji Normalitas Data (Kolmogorov-Smirnov Test)}

Pengujian normalitas data menggunakan uji kolmogorov-smirnov test bertujuan untuk mengetahui apakah sampel yang digunakan dalam penelitian ini berdistribusi normal atau tidak. Jika data berdistribusi normal maka uji hipotesis yang digunakan adalah uji statistik parametrik berupa paired sample $t$-test, dan jika data tidak terdistribusi secara nomal maka uji hipotesis yang digunakan adalah uji statistik non-parametrik berupa wilcoxon signed rank test. Menurut Imam Ghozali $(2011 ; 160)$ residual berdistribusi normal jika memiliki nilai signifikansi $>0,05$ sehingga dasar pengambilan keputusan untuk menentukan normalitas data adalah sebagai berikut:

a. jika nilai signifikansi (Asymp.Sig) <0,05, maka data tidak terdistribusi secara normal; dan

b. jika nilai signifikansi (Asymp.Sig) $>0,05$, maka data terdistribusi secara normal.

\section{Paired Sample T-Test dan Wilcoxon Signed Rank Test}

Pengujian terkait perbedaan rata-rata harga saham perusahaan dengan proxy abnormal return antara periode sebelum dan sesudah pengumuman merger dan akuisisi dilakukan dengan uji statistik. Langkah-langkah dalam pengujian ini dilakukan dengan tahapan sebagai berikut.

a. Merumuskan formula untuk pengujian hipotesis.

b. Menentukan tingkat signifikansi. Penelitian ini menggunakan taraf nyata sebesar $5 \%$, dengan derajat kebebasan (degree of freedom) $\mathrm{n}-1$.

c. Melakukan uji paired sample t-test dengan menggunakan alat uji berupa Statistical Product and Service Solutions (SPSS).

d. Mengambil keputusan dengan membandingkan nilai sig. thitung dengan sig. atau taraf nyata, dengan kriteria sebagai berikut:

1) apabila probabilitas (Asymp.Sig) $>0,05$, maka Ho diterima; dan

2) apabila probabilitas (Asymp.Sig) $<0,05$, maka Ho ditolak.

e. Menarik simpulan.

\section{HASIL DAN PEMBAHASAN}

\section{Rata-Rata Abnormal Return}

Untuk mencari nilai abnormal return, maka terlebih dahulu harus dicari nilai return realisasian dan nilai return ekspektasian. Dimana abnormal return diperoleh dari hasil return realisasian dikurangi dengan return ekspektasian. Grafik rata-rata abnormal return yang diperoleh disajikan dalam gambar 4.1 . 


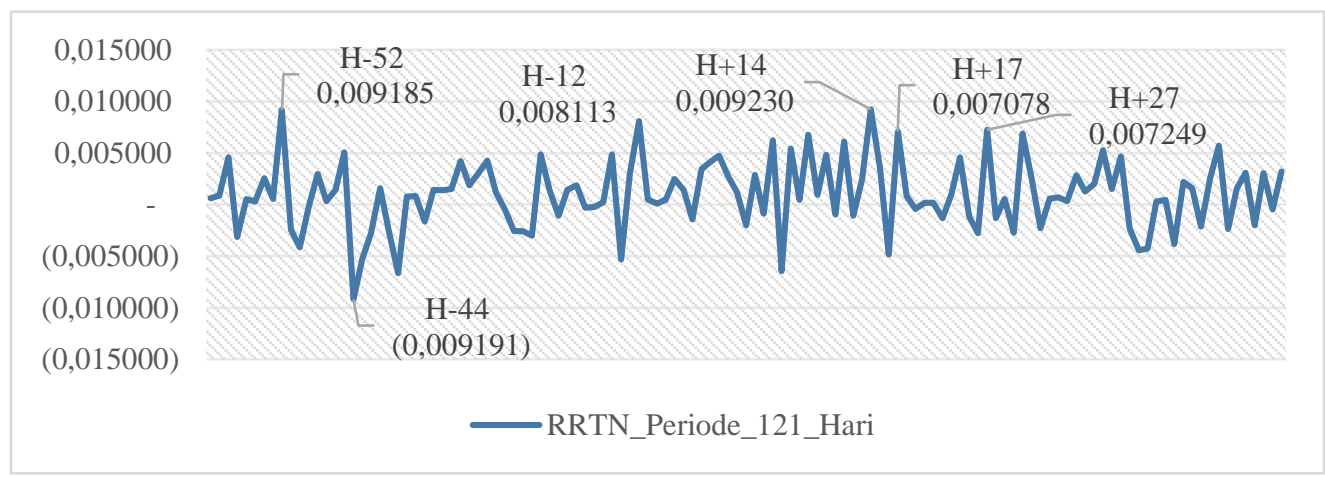

Sumber: Data Diolah penulis (2018)

Gambar 4.1.

Rata-Rata Abnormal Return

Dari gambar 4.1. dapat dilihat bahwa terdapat beberapa nilai yang lebih menonjol/ekstrim dari nilai lainnya, nilai-nilai yang penulis tampilkan pada grafik di atas adalah nilai-nilai yang lebih besar dari 0,007000. Dari grafik tersebut telihat bahwa nilai ratarata abnormal return positif tertinggi terjadi pada hari ke-14 setelah hari pengumuman merger dan akuisisi, dan nilai rata-rata abnormal return negatif terjadi pada hari ke-44 sebelum hari pengumuman merger dan akuisisi. Jika dilihat pada grafik tersebut, secara keseluruhan rata-rata abnormal return yang terjadi pada hari disekitar pengumuman merger dan akuisisi cenderung stabil dan tidak menunjukkan adanya tren atau fluktuasi yang berlebihan. Hasil ini belum dapat dijadikan sebagai simpulan, untuk itu perlu melihat signifikansi hasil rata-rata abnormal return secara statistik agar dapat ditarik simpulan yang tepat dan mendasar.

\section{Pengujian Normalitas Data}

Hasil pengujian normalitas data menggunakan teknik one sample kolmogorov smirnov test diketahui bahwa:

a. nilai asymp.sig (2-tailed) untuk data rata-rata abnormal return sebelum pengumuman merger dan akuisisi adalah sebesar 0,013, yang berarti nilai 0,013<0,05; dan

b. nilai asymp.sig (2-tailed) untuk data rata-rata abnormal return sesudah pengumuman merger dan akuisisi adalah sebesar 0,058, yang berarti nilai 0,058 >0,05.

Berdasarkan hal tersebut, maka dapat disimpulkan bahwa dari dua data yang diuji normalitasnya terdapat satu data yang berdistribusi normal dan satu data yang tidak berdistribusi normal, sehingga penelitian ini akan dilakukan dengan menggunakan uji statistik non-parametrik berupa wilcoxon signed rank test. 


\section{Pengujian Abnormal Return Menggunakan Metode Event Study}

Pengujian ini dilakukan dengan mencari nilai rata-rata return tak normal standarisasi (standardized abnormal return) atau dalam hal ini disebut t-hitung dengan cara membagi nilai rata-rata abnormal return dari semua sekuritas yang diteliti dengan kesalahan standar estimasi di setiap hari dalam periode yang dilakukan penelitian. Kemudian nilai rata-rata abnormal return standarisasi atau dalam hal ini disebut t-hitung yang diperoleh dibandingkan

Tabel 4.2.

Hasil Perhitungan Signifikansi Rata-Rata Abnormal Return

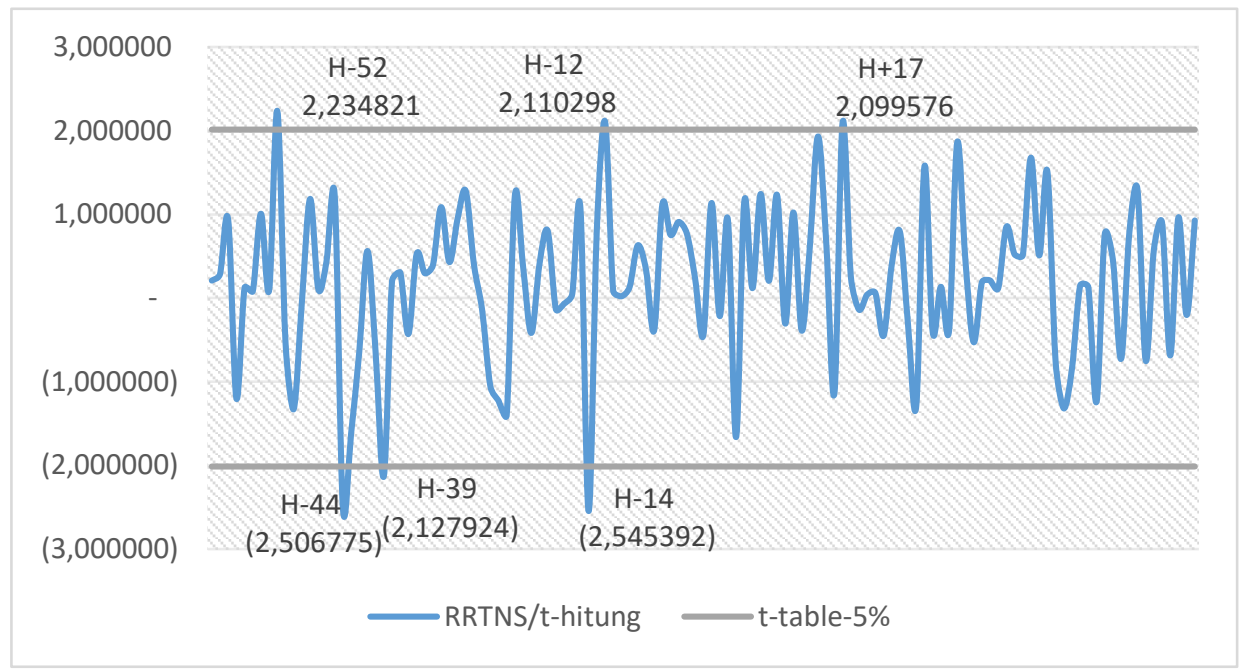

Sumber: Data Diolah penulis (2018)

dengan nilai t-tabel untuk ditarik simpulannya. Hasil perhitungan tersebut penulis tampilkan dalam gambar 4.2. sebagai berikut.

Dari grafik 4.2. telihat bahwa selama periode pengamatan 121 hari yang dimulai dari 60 hari sebelum sampai dengan 60 hari sesudah pengumuman merger dan akuisisi, secara statistik hanya terdapat 6 hari yang menghasilkan abnormal return yang signifikan, dengan rincian sebagai berikut.

a. Pengelompokkan berdasarkan abnormal return positif dan abnormal return negatif.

1) Terdapat 3 hari dimana abnormal return positif yang signifikan terjadi, yaitu pada $\mathrm{H}$ 52, $\mathrm{H}-12$, dan $\mathrm{H}+17$, dengan nilai abnormal return yang diperoleh untuk:
a) $\mathrm{H}-52$ adalah sebesar 2,234821;
b) $\mathrm{H}-12$ adalah sebesar 2,1110298; dan
c) $\mathrm{H}+17$ adalah sebesar 2,099576 .

2) Terdapat 3 hari dimana abnormal return negatif yang signifikan terjadi, yaitu pada $\mathrm{H}$ 44, $\mathrm{H}-39$, dan $\mathrm{H}-14$, dengan nilai abnormal return yang diperoleh untuk:
a) H-44 adalah sebesar -2,056775;
b) H-39 adalah sebesar $-2,127924$; dan 
c) $\mathrm{H}-14$ adalah sebesar $-2,545392$.

b. Pengelompokkan berdasarkan periode abnormal return sebelum dan abnormal return sesudah pengumuman merger dan akuisisi.

1) Terdapat 5 hari dimana abnormal return yang signifikan terjadi pada periode sebelum pengumuman merger dan akuisisi, yaitu pada $\mathrm{H}-52, \mathrm{H}-44, \mathrm{H}-39, \mathrm{H}-14$, dan $\mathrm{H}-12$, dengan nilai rata-rata abnormal return yang diperoleh untuk:
a) H-52 adalah sebesar 2,234821;
b) H-44 adalah sebesar -2,056775;
c) H-39 adalah sebesar -2,127924;
d) $\mathrm{H}-14$ adalah sebesar $-2,545392$; dan
e) $\mathrm{H}-12$ adalah sebesar 2,1110298 .

2) Terdapat satu hari dimana abnormal return yang signifikan terjadi pada periode sesudah pengumuman merger dan akuisisi, yaitu pada $\mathrm{H}+17$, dengan nilai abnormal return yang diperoleh adalah sebesar 2,099576.

Dari data tersebut, terlihat bahwa selama periode pengamatan 121 hari hanya terdapat 6 hari terjadinya abnormal return yang signifikan, sehingga periode ini tergolong sangat singkat. Jika dikelompokkan berdasarkan abnormal return positif dan negatif, maka abnormal return yang positif terjadi selama 3 hari dan abnormal return yang negatif juga terjadi selama 3 hari. Jika dikelompokkan berdasarkan periode abnormal return sebelum dan abnormal return sesudah pengumuman merger dan akuisisi, maka abnormal return terjadi pada 5 hari sebelum dan satu hari sesudah pengumuman merger dan akuisisi. Untuk hari $\mathrm{H}$ pengumuman merger dan akuisisi dan hari lainnya dalam periode pengamatan, abnormal return yang terjadi tidak signifikan secara statistik. Hal ini tentu saja menunjukkan bahwa terdapat 3 hari dimana pasar memberikan respon yang positif dan 3 hari dimana pasar memberikan respon yang negatif terhadap pengumuman merger dan akuisisi yang terjadiDengan demikian, hipotesis null $(\mathrm{H} 0)$ ditolak dan $\mathrm{H} 1$ diterima, atau dengan kata lain ditemukan return tak normal (abnormal return) yang signifikan di sekitar pengumuman merger dan akuisisi.

Akan tetapi, hal yang perlu diingat adalah dari periode pengamatan selama 121 hari di sekitar pengumuman merger dan akuisisi, hanya terdapat 6 hari dimana abnormal return yang signifikan (baik positif maupun negatif) terjadi. Karena jika dilihat dari grafik 4.2. secara keseluruhan pergerakan abnormal return di sekitar pengumuman merger dan akuisisi cenderung statis dan tidak menunjukkan suatu hal yang berkelanjutan atau terus menerus. 


\section{Pengujian Perbedaan Abnormal Return Sebelum dan Sesudah Pengumuman Merger} dan Akuisisi

Dalam melakukan pengujian terhadap perbedaan abnormal return saham antara periode sebelum dan sesudah pengumuman merger dan akuisisi, penulis menggunakan pendekatan statistik inferensial dengan menggunakan uji statistik non-parametrik berupa wilcoxon signed rank test karena dari hasil pengujian normalitas data yang dilakukan diketahui bahwa terdapat satu data yang tidak berdistribusi normal. Dalam pengujian hipotesis 2 ini, penulis akan melakukan pengujian terhadap data abnormal return sebelum dan sesudah pengumuman merger dan akuisisi untuk mengetahui apakah terdapat perbedaan rata-rata abnormal return yang signifikan pada harga saham perusahaan pengakuisisi yang melakukan merger dan akuisisi antara periode sebelum dan sesudah efektifnya merger dan akuisisi yang dilakukan. Periode yang diamati adalah selama 60 hari sebelum dan 60 hari sesudah pengumuman merger dan akuisisi. Pengujian ini diawali dengan mencari nilai rata-rata abnormal return sebelum dan nilai rata-rata abnormal return sesudah pengumuman atau efektifnya merger dan akuisisi. Kemudian nilai rata-rata abnormal return sebelum dan sesudah pengumuman atau efektifnya merger dan akuisisi tersebut dilakukan pengujian dengan metode wilcoxon signed rank test. Hasil perhitungan tersebut penulis tampilkan dalam tabel 4.3.

Tabel 4.3.

Hasil Pengujian Wilcoxon Signed Rank Test

\begin{tabular}{|l|l|r|r|r|}
\hline \multicolumn{5}{|c|}{ Ranks } \\
\hline \multirow{4}{*}{ Sesudah_M\&A - Sebelum_M\&A } & Negative Ranks & $22^{\mathrm{a}}$ & Mean Rank & Sum of Ranks \\
\cline { 2 - 5 } & Positive Ranks & $25^{\mathrm{b}}$ & 25.18 & 488.00 \\
\cline { 2 - 5 } & Ties & $0^{\mathrm{c}}$ & & 640.00 \\
\cline { 2 - 5 } & Total & 47 & & \\
\hline $\begin{array}{l}\text { a. Sesudah_M\&A < Sebelum_M\&A } \\
\text { b. Sesudah_M\&A > Sebelum_M\&A } \\
\text { c. Sesudah_M\&A = Sebelum_M\&A }\end{array}$
\end{tabular}

\begin{tabular}{|l|r|}
\hline \multicolumn{2}{|c|}{ Test Statistics $^{\text {a }}$} \\
\hline Z & \multicolumn{1}{|c|}{$\begin{array}{l}\text { Sesudah_M\&A - } \\
\text { Sebelum_M\&A }\end{array}$} \\
\hline $\begin{array}{l}\text { Asymp. Sig. (2- } \\
\text { tailed) }\end{array}$ \\
\hline $\begin{array}{l}\text { a. Wilcoxon Signed Ranks Test } \\
\text { b. Based on negative ranks. }\end{array}$ \\
\hline
\end{tabular}

Sumber: Data Diolah penulis (2018) 
Dari tabel 4.3. terlihat bahwa rata-rata abnormal return periode sebelum dan sesudah pengumuman merger dan akuisisi memiliki nilai signifikansi atau asymp.sig (2-tailed) sebesar 0,421, yang berarti nilai 0,421 >0,05. Nilai signifikansi ini jauh lebih besar dari 0,05, yang menggambarkan bahwa nilai rata-rata abnormal return sebelum dan sesudah pengumuman merger dan akuisisi adalah sama atau tidak berbeda, sehingga pengumuman merger dan akuisisi tidak memberikan pengaruh secara signifikan terhadap rata-rata abnormal return. Dengan demikian hipotesis null $(\mathrm{H} 0)$ diterima dan $\mathrm{H} 1$ ditolak, atau dengan kata lain tidak terdapat perbedaan abnormal return yang signifikan antara periode sebelum dan sesudah pengumuman merger dan akuisisi.

\section{SIMPULAN}

Berdasarkan pengujian menggunakan metode event study, disimpulkan bahwa terdapat pengaruh berupa abnormal return return yang signifikan pada harga saham perusahaan pengakuisisi yang melakukan merger dan akuisisi yang terdaftar di Bursa Efek Indonesia di sekitar tanggal efektifnya merger dan akuisisi. Sementara itu berdasarkan uji beda menggunakan metode wilcoxon signed rank test, disimpulkan bahwa tidak terdapat perbedaan rata-rata abnormal return yang signifikan pada harga saham perusahaan pengakuisisi yang melakukan merger dan akuisisi yang terdaftar di Bursa Efek Indonesia antara periode sebelum dan sesudah efektifnya merger dan akuisisi.

Secara keseluruhan, penulis dapat menyimpulkan bahwa pengumuman merger dan akuisisi tidak menghasilkan return tak normal (abnormal return) yang signifikan pada harga saham perusahaan pengakuisisi yang melakukan merger dan akuisisi karena return tak normal (abnormal return) sebelum dan sesudah pengumuman merger dan akuisisi tidak berbeda atau sama secara statistik, meskipun disekitar pengumuman merger dan akuisisi tersebut terdapat return tak normal (abnormal return) yang signifikan secara statistik pada 5 hari sebelum dan 1 hari sesudah hari pengumuman merger dan akuisisi.

\section{DAFTAR PUSTAKA}

Christensen, T. E., D.M. Cottrell, and R.E. Baker. 2014. "Advanced Financial Accounting". Tenth Edition. New York: Mc Graw-Hill/Irwin.

Darmadji, Tjiptono dan Hendy M. Fakhruddin. 2012. "Pasar Modal Di Indonesia”. Jakarta: Salemba Empat.

Elad, Fotoh Lazarus. 2017. "Event Study on the Reaction of Stock Returns to Acquisition News". International Finance and Banking Vol.4, No. 1: 33-43.

Ghozali, Imam. 2011. "Aplikasi Analisis Multivariative dengan Program IBM SPSS 19". Edisi

5. Semarang: Badan Penerbit Universitas Diponegoro. 
Gitman, Lawrence. 2009. "Principles of Manajerial Finance". United States: Pearson Addison Wesley.

Hartono, Jogiyanto. 2017. "Teori Portofolio dan Analisis Investasi". Edisi Kesebelas. Yogyakarta : BPFE-Yogyakarta.

Indriantoro, Nur dan Bambang Supomo. 2016. "Metodologi Penelitian Bisnis untuk Akuntansi dan Manajemen”. Edisi Pertama. Yogyakarta. BPFE-Yogyakarta.

Ikatan Akuntan Indonesia (IAI). 2017. "Standar Akuntansi Keuangan". PSAK. Jakarta: Salemba Empat, Jakarta.

Moin, Abdul. 2010. "Merger, Akuisisi, \& Divestasi". Edisi Kedua. Cetakan Ketiga. Yogyakarta: Ekonisia.

Rahman, Zahoor, Arshad Ali, and Khalil Jebran. 2017. "The effects of mergers and acquisition on stock price behavior in banking sector of Pakistan". The Journal of Finance and Data Science 4 (2018): 44-54.

Subramanyam, K. R. dan John J. Wild. 2016. "Analisis Laporan Keuangan (Financial Statement Analysis)". Buku Satu. Edisi Sepuluh. Cetakan Kedelapan. Jakarta: Salemba Empat.

Tandelilin, Eduardus. 2017. "Pasar Modal Manajemen Portofolio dan Investasi". Yogyakarta: Kanisius. 